\title{
In Vitro, Controlling the Establishment of Xanthomonas Campestris with different Bacterial Bioagents
}

\author{
Amna Ali*1, M. Saleem Haider ${ }^{2}$, Sobia Mushtaq ${ }^{1}$, Ibatsam Khokhar ${ }^{1}$, Irum Mukhtar ${ }^{1}$, Sana Hanif ${ }^{2}$ and Nosheen \\ Akhtar $^{2}$ \\ ${ }^{1}$ First Fungal Culture Bank of Pakistan (FCBP), Institute of Agriculture Sciences (IAGS), University of the Punjab, Lahore, 54590, Pakistan. ${ }^{2}$ Institute of \\ Agriculture Sciences (IAGS), University of the Punjab, Lahore, 54590, Pakistan
}

\begin{abstract}
The antimicrobial agents of bacteria isolated from different rhizosphere of fruits and vegetables soil in Lahore. Of ten species, five were gram-negative (Escherichia coli, Pseudomonas fluorescence, Klebsiella pneumoniae, Salmonella typhii, Brachybacterium faecium); other five were gram positive and identified as Bacillus farraginis, Kurthia gibsonii, Aureobacterium liquefaciens, Curtobacterium albidum, Micrococcus lylae. The antagonistic potential of bacterial strains was assessed by the well diffusion technique and results indicating varying degree of biocontrol activity against pathogenic strain of $X$. campestris. Out of ten bacterial species, $E$. coli (gram negative) and $C$. albidum (gram positive) showed a high prevalence of resistance with reduction of $4.2 \mathrm{~cm}$ and $4.1 \mathrm{~cm}$ zone diameter respectively. The minimum inhibitory volume (MIV) to two bio-agents was determined for $X$. campestris from range 10-100 $\mu \mathrm{L}$. E. coli (volume required to inhibit $<20 \mu \mathrm{L}$ ) and $C$. albidum (volume required to inhibit $<40 \mu \mathrm{L}$ ) exhibited good activity against pathogen. These results provide information on the prevalence of resistant bacterial strains with the MIV of organisms and indicate the possibility of using these bacterial species as bio-agent against $X$. campestris.
\end{abstract}

Key words: Xanthomonas campestris, gram positive bacteria, gram negative bacteria

\section{Introduction}

The genus Xanthomonas is a diverse and economically essential group of bacterial phytopathogens, belonging to the gammasubdivision of the Proteobacteria. Xanthomonas campestris is the most important member that causes a variety of plant diseases $^{1}$. X. campestris causes different diseases in plant foliage by producing black rot, canker, leaf spot and blights. These diseases may destroy leaves, petioles and stems rendering infected plants unsightly and unsalable ${ }^{2,3}$.

The use of chemical compounds has failed to control plant diseases due to resistance, environment pollution, and damage to human health. Because of these disadvantages, the use of microorganisms for pathogen control and for plant growth promotion is becoming more common ${ }^{4}$. However, the success of biocontrol and yield increase depends on the nature of the antagonistic properties and on the mechanisms of action of the organism. The modes of action are widely varied and can be, for instance, nutrient competition, direct parasitism, and production of secondary metabolites ${ }^{5}$. Biological control of plant pathogens using antagonistic bacteria is a promising strategy for plant protection ${ }^{6}$.

Bacillus species, gram-positive bacteria, are good biological control agents (BCA) for, their ability to produce different types of antimicrobial compounds, such as antibiotics (e.g., bacilysin, iturin, mycosubtilin), siderophores and to induce growth and defense responses in the host plant ${ }^{7,8}$. However, gram-negative bacteria belonging to Pseudomonas genera significant attention for antagonistic activity ${ }^{7-11}$. The aim of this work was to evaluate biocontrol potential of different gram positive and gram negative bacterial species against pathogenic strain of Xanthomonas campestris.

\section{Materials and Methods \\ Isolation of bacterial bioagents}

Soil samples were randomly collected from four different sites near Lahore, Pakistan, in sterilized plastic bags until (Table 1). The samples were processed using the soil dilution plate ${ }^{12}$. For soil dilution, one gram of soil diluted in $10 \mathrm{ml}$ of sterilized distilled water, course partials were removed by filtration through a layer of gauze. One $\mathrm{ml}$ of filtrate was used to make serial dilution of soil samples up to $10^{5}$. For bacterial isolation, $1 \mathrm{ml}$ of $10^{5}$ dilutions was added on solidified Luria Bertani (L.B) agar medium (g/L) plates. The dilution was spread with sterilized spreader and the plates were placed in an incubator at $37^{\circ} \mathrm{C}$ for 24 hours. Distinct individual colonies purified by streaking on a new nutrient agar plate. Pure cultures were identified according to the literature ${ }^{13}$. Selected bacterial species were: gram positive (Bacillus farraginis, Kurthia gibsonii, Aureobacterium liquefaciens Curtobacterium albidum, Micrococcus lylae) and gram negative (Escherichia coli, 
Pseudomonas fluorescence Klebsiella pneumoniae, Salmonella typhii, Brachybacterium faecium).

\section{Pathogen}

A bacterial strain, Xanthomonas compestris (FCBP 001) used for this study was obtained from First fungal Culture Bank of Pakistan (FCBP), University of the Punjab Lahore (Table 1). Cultures were revived on Luria Bertani (L.B) agar media at $37 \pm 2$ ${ }^{\circ} \mathrm{C}$ and used for further studies.

Table 1: List of bacterial bioagent

\begin{tabular}{lll}
\hline Name of bioagent & Source & Location \\
\hline Gram Positive Bacteria & & \\
Bacillus farraginis & Wheat field soil & Lahore \\
Kurthia gibsonii & Vegetable field soil & Lahore \\
Aureobacterium liquefaciens & Vegetable field soil & Lahore \\
Curtobacterium albidum & Gram field soil & Lahore \\
Micrococcus lylae & Vegetable field soil & Lahore \\
Gram Negative Bacteria & & \\
Escherichia coli & Mango field soil & Lahore \\
Pseudomonas fluorescence & Vegetable field soil & Lahore \\
Klebsiella pneumonia & Sugarcane field soil & Lahore \\
Salmonella typhii & Sugarcane field soil & Lahore \\
Brachybacterium faecium & Vegetable field soil & Lahore \\
\hline
\end{tabular}

\section{Preparation of the bacterial suspensions}

The antagonistic and pathogenic strains were grown on Luria Bertani (L.B) agar media plates separately, incubated at $37 \pm 2$ ${ }^{\circ} \mathrm{C}$ for $24 \mathrm{~h}$. Inocula of each strain were prepared by adding $5 \mathrm{~mL}$ of a sterile saline solution $(0.85 \% \mathrm{NaCl})$ to the Petri dishes. The cultures were scraped with a glass rod and the suspensions homogenized by agitation in a Vortex mixer. The amount of inoculum was measured in a spectrophotometer and adjusted with sterile saline solution $(\mathrm{OD} 600=0.1$ was equivalent to $1 \times 10^{8}$ colony forming units $\left.(\mathrm{CFU}) / \mathrm{ml}\right)^{14}$.

\section{Antimicrobial bioassays}

A bacterial suspension for inocula and bioagents from 24h old culture were used by well diffusion method. Petri dishes (90 $\mathrm{mm}$ ) containing Luria Bertani (L.B) agar medium were surface inoculated with $0.08 \mathrm{ml}$ of bacterial inocula. After $15 \mathrm{~min}$ inoculation, one well of $8 \mathrm{~mm}$ diameter was dug out in the agar medium, filled with $0.07 \mathrm{ml}$ of bioagent suspensions. After $24 \mathrm{~h}$ incubation at $37^{\circ} \mathrm{C}$, the antibacterial effect was determined by measurement of the inhibition zone diameters.

\section{Determination of Minimum Inhibitory Volume}

The maximum inhibition diameter of above gram positive and negative bacterial species was checked again by minimum inhibitory volume. The bioagent suspensions were loaded into sterile well on L.B agar medium in different volumes of $10 \mu \mathrm{L}$, $20 \mu \mathrm{L}, 30 \mu \mathrm{L}, 40 \mu \mathrm{L}, 50 \mu \mathrm{L}, 60 \mu \mathrm{L}, 70 \mu \mathrm{L}, 80 \mu \mathrm{L}, 90 \mu \mathrm{L}$ and $100 \mu \mathrm{L}$ concentration respectively and allowed to incubated for 24 hours at $37^{\circ} \mathrm{C}$, the minimum inhibitory volume effect was determined by measurement of the inhibition zone diameters.

\section{Statistical evaluation}

The antimicrobial activity was determined by measuring the diameter of zone of inhibition that is the mean of triplicates \pm SE of three replicates.

\section{Results}

Screening of gram positive bacterial strains

Five gram positive bacterial species viz. B. farraginis, $K$. gibsonii A. liquefaciens, C. albidum and M. lylae were screened for their antagonistic activity against $X$. campestris. Experimental results showed that all tested bacterial species show varying degree of biocontrol potential against $X$. campestris (Fig. 1). C. albidum showed effective biocontrol potential with $4.1 \mathrm{~cm}$ diameter of inhibition zone. While in case of $K$. gibsonii and M. lylae, zone diameters were effectively reduce upto $2.2 \mathrm{~cm}$. On the other hand $B$. farraginis and $A$. liquefaciens were moderately effective and reduced the pathogenic colony with $3.1 \mathrm{~cm}$ and $3.0 \mathrm{~cm}$ zone diameter respectively.

\section{Selection of gram negative bacterial strains}

Five gram negative bacterial species viz. E. coli, P. fluorescence, K. pneumoniae, S. typhii and B. faecium were screened for their antagonistic activity (Fig. 1). E. coli showed most effective biocontrol potential with $4.2 \mathrm{~cm}$ whereas $P$. fluorescence was weak to least effective to control the growth of $X$. campestris. While in case of $K$. pneumoniae and $B$. faecium, were effectively reduced the zone upto $2.4 \mathrm{~cm}$ and $2.3 \mathrm{~cm}$ diameters, respectively. Although, S. typhii was moderately effective against the pathogenic species with $3.0 \mathrm{~cm}$ zone diameter.

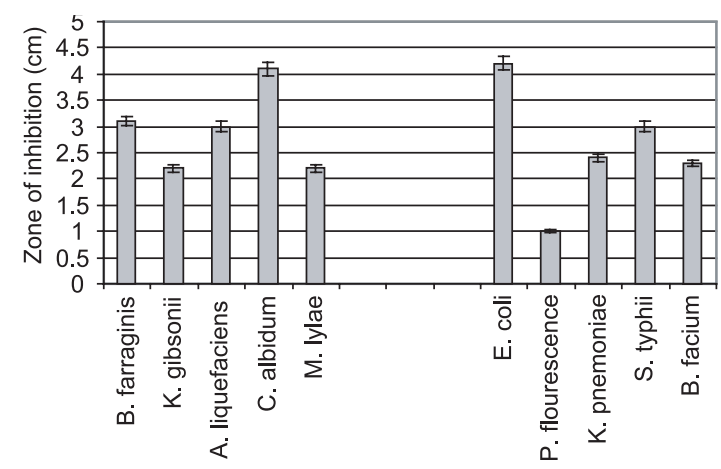

Fig 1: Diameter of Inhibition zone of Gram positive and Gram negative bacteria

Comparison of gram positive and gram negative bacteria antagonism with Minimum Inhibitory volume

The volume of antagonistic bacteria fell in the range of $10 \mu \mathrm{L}$ to $100 \mu \mathrm{L}$ for C. albidum (gram positive) and E. coli (gram negative) (Table 2). Table 2 also shows that the gram negative species of $E$. coli detected the most potent inhibition for $X$. campestris as compared to gram positive species. The minimum inhibitory volume of $C$. albidum that completely stopped the growth of $X$. campestris was $<40 \mu \mathrm{L}$ and it's above. On the other hand, only volumes of $<20 \mu \mathrm{L}$ completely inhibit the growth of pathogen in case of $E$. coli. 
Table 2: Minimum inhibitory volume for gram positive and gram negative bacterial species against $X$. campestris

\begin{tabular}{lcc}
\hline \multirow{2}{*}{$\begin{array}{l}\text { Minimum Inhibitory } \\
\text { volume }\end{array}$} & \multicolumn{2}{c}{ Diameter of Inhibition Zone (cm) } \\
\cline { 2 - 3 } & $\begin{array}{c}\text { Curtobacterium } \\
\text { albidum (gram +ve) }\end{array}$ & $\begin{array}{c}\text { Escherichia } \\
\text { coli (gram -ve) }\end{array}$ \\
\hline $10 \mu \mathrm{L}$ & na & na \\
$20 \mu \mathrm{L}$ & na & na \\
$30 \mu \mathrm{L}$ & na & $0.43 \pm 0.03$ \\
$40 \mu \mathrm{L}$ & na & $1.20 \pm 0.16$ \\
$50 \mu \mathrm{L}$ & $1.90 \pm 0.03$ & $2.10 \pm 0.03$ \\
$60 \mu \mathrm{L}$ & $2.10 \pm 0.13$ & $3.00 \pm 0.03$ \\
$70 \mu \mathrm{L}$ & $2.90 \pm 0.06$ & $3.60 \pm 0.10$ \\
$80 \mu \mathrm{L}$ & $3.70 \pm 0.03$ & $4.00 \pm 0.03$ \\
$90 \mu \mathrm{L}$ & $3.90 \pm 0.03$ & $4.10 \pm 0.03$ \\
$100 \mu \mathrm{L}$ & $4.00 \pm 0.03$ & $4.40 \pm 0.03$ \\
\hline
\end{tabular}

na: pathogen not active at volume range

\section{Discussion}

The results indicated that $X$. campestris showed antibacterial activities towards the Gram-positive and Gram negative bacteria. These results are consistent with previous reports on related food borne fungi regarding Gram-positive and Gram negative bacteria $^{15}$. The resistance of Gram-negative bacteria to pathogen was not unexpected as; in general, this class of bacteria is more resistant than Gram-positive bacteria. Such resistance could be due to the permeability barrier provided by the cell wall or to the membrane accumulation mechanism ${ }^{16}$.

This study showed variation in antimicrobial potential among different soil bacterial isolates. All bacterial isolates exhibited antimicrobial activity against tested pathogen. The high proportion of antimicrobial producing strains may be associated with an ecological role, playing a defensive action to maintain their niche, or enabling the invasion of a strain into an established microbial community ${ }^{17}$.

Results indicated that exhibited maximum inhibitory activity whereas K. gibsonii and M. lylae was less effective as in case of gram positive bacteria. Although different studies reported the antimicrobial potential of $C$. albidum against pathogenic fungi, like Alternaria cajani, Curvularia lunata, Fusarium sp., Bipolaris sp. and Helminthosporium sp. ${ }^{18}$. Results also showed that $B$. farraginis and $A$. liquefaciens were moderately effective and exhibited almost similar biocontrol potential against $X$. campestris. Previously, antifungal potential of Bacillus sp, Pseudomonas sp. and Escherichia sp. has also been reported to inhibit the mycelial growth of many species of Aspergillus, Penicillium and Fusarium ${ }^{15,19,20 .}$

In present study, Escherichia coli showed highly effective biocontrol prospective against $X$. campestris where it reduce the pathogenic growth with $4.2 \mathrm{~cm}$ zone diameter. But other studies have reported cytosolic proteins of Escherichia coli are responsible for antimicrobial potential against pathogenic strains $^{15,21,22}$. Our results demonstrate that the growth of $X$. campestris was remarkably inhibited by the minimum inhibitory volume of E. coli $(0.43 \mathrm{~cm} /<30 \mu \mathrm{L}$ inhibition zone) and $C$. albidum ( $1.90 \mathrm{~cm} /<50 \mu \mathrm{L}$ inhibition zone). It seems very likely, therefore, that the antibacterial compound from bioagents may inhibit pathogen by a different mechanism than that of currently used antibiotics and may have therapeutic value as an antibacterial agent against multi-drug resistant bacterial strains and must be better explored in future. The presented data exhibit the antimicrobial activity of bacterial species and indicate the possibility of using these bacterial species as a biological agent to control pathogenic species. However, biological agents tested in this study should be investigated extensively for food safety before commercialization.

\section{References}

1. Starr MP and Stephens WL. 1964. Pigmentation and taxonomy of the genus Xanthomonas. J. bacteriol. 87: 293-302.

2. Mariano RLR, Silveira EB, Assis SMP, Gomes AMA, Oliveira IS and Nascimento ARP. 2001. Diagnose e manejo de fitobacterioses de importância no Nordeste Brasileiro. In: Michereff, S. J. and Barros, R. (Eds.). Proteção de Plantas na Agricultura Sustentável. Recife. pp. 141-169.

3. Assis SMP, Mariano RLR, Michereff SJ and Coelho RSB. 1997. Antagonism of Bacillus spp. to Xanthomonas campestris pv. campestris on cabbage phyloplane in the field, pp 345-348. Proceedings of the Fourth International Workshop on Plant Growth- Promoting Rhizobacteria - Present Status and Future Prospects. Japan: OECD.

4. Thomashow LS and Weller DM. 1996. Current concepts in the use of introduced bacteria for biological disease control: mechanisms and antifungal metabolites. In: Stacey, G. and Keen, N. T. (Eds.). Plant-Microbe Interactions, vol 1, pp 187-235. New York: Chapman and Hall.

5. Melo IS. 1998. Agentes microbianos de controle de fungos fitopatogênicos, vol 1, pp 17-30. In: Melo, I. S. and Azevedo, J. L. (Eds.). Controle Biológico. Embrapa, Jaguariúna.

6. Kloepper JW, Rodr'ýguez-K’abana R, Zehnder GW, Murphy JF, Sikora E and Fern' andez C. 1999. Plant root-bacterial interactions in biological control of soilborne diseases and potential extension to systemic and foliar diseases. Australasian Plant Pathol. 28: 21-26.

7. Shoda M. 2000. Bacterial control of plant diseases. J. Bioscience and Bioengineering. 89: 515-521.

8. Raupach GS and Kloepper JW. 1998. Mixtures of plant growth-promoting rhizobacteria enhance biological control of multiple cucumbers. Phytopathol. 88: 1158-1164.

9. Braun-Kiewnick A, Jacobsen BJ and Sands DC. 2000. Biological control of Pseudomonas syringae pv, the causal agent of basal kernel blight of barley, by antagonistic Pantoea agglomerans. Phytopathol. 90: 368-375.

10. Costa E, Teixido N, Usall J, Atarés E and Viñas I. 2001. Production of the biocontrol agent Pantoea aglomerans strain CPA-2 using commercial products and by-products. Appl. Microbiol. Biotechnol. 56(3-4): 367-371.

11. Slininger PJ, Burkhead KD, Schihsler DA and Bothats RJ. 2000. Isolation, identification and accumulation of 2-acetamidophenol in liquid cultures of the wheat take-all biocontrol agent Pseudomonas fluorescens. Appl. Microbiol. Biotechnol. 54: 376-381.

12. Waksman SA. 1922. A method of counting the number of fungi in the soil. J. Bacteriol. 7: 339-341.

13. Holt J, Krieg N, Sneath P, Staley J and Williams S. 1994. Bergey's Manual of Determinative Bacteriology, $9^{\text {th }}$ edn. Williams and Wilkins, Baltimore, USA.

14. Ednar GW, Cames MM, Carmen NM, Chandroo LK and John. 2002. Biological control of black rot (Xanthomonas campestris pv. campestris) of brassicas with an antagonistic strain of Bacillus subtilis in Zimbabwe. European J. Plant Pathol. 108: 317-325, 
15. Mushtaq S, A Ali, I Khokhar and I Mukhtar. 2010. Antagonisitic Potential of Soil Bacteria Against Food Borne Fungi. World Appl. Sci. J. 11(8): 966969.

16. Adwan K and Abu-Hasan N. 1998. Gentamicin resistance in clinical strains of Enterobacteriaceae associated with reduced gentamicin uptake. Folia Microbiol. 43: 438-40, 1998.

17. Motta AS, Cladera-Olivera F. and Brandelli A. 2004. Screening for antimicrobial activity among bacteria isolated from the Amazon basin. Brazil. J. Microbiol. 35: 307-310.

18. Srivastava R. and Shalni M. 2008. Antifungal Activity of Curtobacterium albidum Against Different Plant Pathogenic Fungi. Electronic J. Env. Agri. Food Chem. 7: 2789-2796.
19. Nourozian J, Etebarian HR and Khodakaramian G. 2006. Biological control of Fusarium graminearum on wheat by antagonistic bacteria, Songklanakarin. J. Sci. and Technol. 28: 29-38.

20. Munimbazi C. and Bullerman LB. 1998. Isolation and partial characterization of antifungal metabolites of Bacillus pumilus. J. Appl. Microbiol. 84: 959968.

21. Yadav V, Mandhan R, Pasha Q, Pasha S, Katyal A, Chhillar AK, Gupta J, Dabur R and Sharma GL. 2007. An antifungal protein from Escherichia coli. J. Med. Microbiol. 56: 637-644.

22. Yadav V, Mandhan R, Kumar M, Gupta J and Sharma GL. 2010. Characterization of the Escherichia coli Antifungal Protein PPEBL21. International J. Microbiol. Doi: 10.1155/2010/196363. 